\title{
Some Features of the Influence of Titanium and Nitrogen Addition to NiCrMoV Steel
}

\author{
Saeed Ghali*, Mamdouh Eissa, Michael Mishreky \\ Steel Technology Department, Central Metallurgical Research \& Development Institute (CMRDI), Cairo, Egypt \\ Email: *a3708052@yahoo.com
}

How to cite this paper: Ghali, S., Eissa, M. and Mishreky, M. (2018) Some Features of the Influence of Titanium and Nitrogen Addition to NiCrMoV Steel. Journal of Minerals and Materials Characterization and Engineering, 6, 203-217.

https://doi.org/10.4236/jmmce.2018.62015

Received: November 11, 2017

Accepted: March 17, 2018

Published: March 20, 2018

Copyright () 2018 by authors and Scientific Research Publishing Inc. This work is licensed under the Creative Commons Attribution International License (CC BY 4.0).

http://creativecommons.org/licenses/by/4.0/

\begin{abstract}
This paper reports a study of the addition effects of either titanium or titanium and nitrogen of steel grade DIN $56 \mathrm{NiCrMoV} 7$ on mechanical properties. Three steel grades were produced in $30 \mathrm{~kg}$-induction furnace, one conforms the chemical composition of conventional $56 \mathrm{NiCrMoV} 7$ while the other two produced steels were microalloyed by either titanium or titanium and nitrogen. The produced cast steel grades were reheated to $1150^{\circ} \mathrm{C}$ and hold for 2 hours, followed by forging process. The forging process was carried out in temperature range $950^{\circ} \mathrm{C}-1100^{\circ} \mathrm{C}$. Solution treatment of hot forged steels was conducted at $880^{\circ} \mathrm{C}, 850^{\circ} \mathrm{C}$ followed by air and oil quenching, respectively. Quenched steel samples of different steel grades were tempered at different temperatures in the range of $300^{\circ} \mathrm{C}$ to $650^{\circ} \mathrm{C}$ for $45 \mathrm{~min}$. The hardness variations after tempering of the two modified steels comparing with the conventional $56 \mathrm{NiCrMoV7}$ steel were studied. Microadditions of titanium or titanium and nitrogen were found to produce secondary hardening at $550^{\circ} \mathrm{C}$ to $575^{\circ} \mathrm{C}(45 \mathrm{~min})$ with a hardness peak higher than that attained in the conventional $56 \mathrm{NiCrMoV7}$ steel. The effect of titanium and nitrogen additions on phases formation was investigated by Thermo-Calc. SEM was used to confirm Thermo-Calc analysis. Interpretation between hardness and formed phases has been illustrated.
\end{abstract}

\section{Keywords}

Thermo-Calc, Tool Steel, Vanadium, Titanium, Nitrogen, Secondary Hardening

\section{Introduction}

In tool steels chromium will form carbides of the types $\mathrm{Cr}_{23} \mathrm{C}_{6}$ and some $\mathrm{Cr}_{7} \mathrm{C}_{3}$ during annealing depending on the chromium content. These carbides dissolve 
during austenitization at temperature exceeding $\sim 900^{\circ} \mathrm{C}$ and are totally dissolved at $\sim 1100^{\circ} \mathrm{C}$. Chromium improves the cutting performance due to formation of wear resistant carbides, and improvement of the tempering resistance [1] [2] [3] [4] [5].

The influence of temperature and time duration of heat treatment of NiCr$\mathrm{MoV}$ steels on precipitates. While, [6] found that after one hour of tempering at $600^{\circ} \mathrm{C}$ only $\mathrm{M}_{3} \mathrm{C}$ carbides were precipitated. These were very rich in iron. As the tempering time increased, the chromium content of the $\mathrm{M}_{3} \mathrm{C}$ carbides increased significantly, but their size did not change. Chromium rich $\mathrm{M}_{7} \mathrm{C}_{3}$ precipitates began to form after 20 hours of tempering, and after 50 hours of tempering Mo-rich $\mathrm{M}_{2} \mathrm{C}$ carbides were precipitated. Also, after 100 hours of tempering, the matrix formed bands rich in $\mathrm{M}_{3} \mathrm{C}$ or $\mathrm{M}_{7} \mathrm{C}_{3}$ and $\mathrm{M}_{2} \mathrm{C}$ particles.

The effects of temperature and holding time on the austenite grain size evolution of NiCrMoV steel on grain size were investigated [7].

The effect of the alloying elements such as phosphorous, tin and molybdenum [7] [8] on microstructure, mechanical and chemical properties was investigated. The effect of microstructure on mechanical properties of $\mathrm{Ni}-\mathrm{Cr}-\mathrm{Mo}-\mathrm{V}$ system was investigated by Qiang Wang et al. [9] and Liu X. [10]. The solution treatment effect on mechanical properties was studied by [11].

It was found that vanadium forms very hard and thermally stable MC type carbides usually as isolated particles. These carbides improve the resistance against abrasive wear and provide very good cutting performance [4] [5] [12]. Vanadium carbides are very limitedly soluble in the matrix, hence addition of vanadium will not delay the rate of diffusion decomposition of austenite

Molybdenum promotes formation of carbides such as $\mathrm{M}_{2} \mathrm{C}$ type [12]. These carbides become unstable at elevated temperatures, and at about $750^{\circ} \mathrm{C}$ they transforms to $\mathrm{M}_{6} \mathrm{C}$ type carbides by reaction with $\mathrm{Fe}$ [12] [13]. Addition of nickel increases the strength of the steel by entering into solid solution in ferrite. It is used in low alloy steels to increase toughness and hardenability. Presence of nickel reduces lattice distortion and cracking during quenching.

Carbides contribute to strengthening of tool steels in two different ways. Firstly, the alloy-carbides are significant harder than the matrix; carbides provide resistance against abrasive wear. Secondly, contribution to the high yield strength of especially some tool steels by impeding the mobility of matrix dislocations. The influence of carbides on strength is due to relatively large carbides (ranging from $1-6 \mu \mathrm{m}$ and up to $25 \mu \mathrm{m}$ in powder metallurgical and conventionally processed tool steels, respectively) embedded in the matrix provides resistance against abrasive wear, especially if they are homogeneously distributed [14]. Precipitated (alloying element) carbides provide enhanced yield strength by hindering of dislocation movement. Precipitates/carbides intersect matrix-slip-planes in a random fashion during growth. When a dislocation gliding in its matrix-slip-plane meets a precipitate, it is forced to either cut through or around it, and it will choose the route offering lowest resistance. 
Titanium is a highly active element, which at room temperature normally forms a stable oxide coating on its surface, which limits further oxidation. At steelmaking temperatures, it forms stable compounds with oxygen, carbon, nitrogen and sulfur. Because of this property, it is often used in steelmaking to fix these elements, so lessening their harmful effects. Titanium also acts as a grain refiner in many steels [15], and in many respects it has a similar function to the addition of both aluminum and niobium.

Microalloying with vanadium, titanium, niobium and nitrogen was emerged as an attractive technique to enhance the mechanical properties of hot deformed steels through grain refinement and precipitation strengthening [16] [17] and attaining higher hardness levels in quenched-tempered steels through secondary hardening [18]. The changes in tempering treatment affect the type of carbide formed and the size, distribution, and chemistry of the various carbides [4].

The objective and novelty of this article is to investigate the effect of micro addition of either titanium or titanium and nitrogen on the carbides formation from the point of their types, compositions and amount and their effect on hardness of tempered steel.

\section{Experimental}

Three steel grades of tool steels with nearly the same contents of nickel, chromium, molybdenum, vanadium and carbon and different contents of titanium and nitrogen were produced. Pilot plant $30 \mathrm{~kg}$-induction furnace was used in producing the investigated steels. The produced ingots were recharged into reheating furnace where hold for 2 hour at temperature $1150^{\circ} \mathrm{C}$ before forging. The forging process was started at $1100^{\circ} \mathrm{C}$ by using load of one ton free forging. The finishing forging temperature was adjusted to be $950^{\circ} \mathrm{C}$ and followed by air cooling. Two groups of hot forged steel samples were subjected to heat treatment process. One group was heated to $880^{\circ} \mathrm{C}$, kept for one hour, followed by air quenching. Another group was heated to $850^{\circ} \mathrm{C}$, kept for one hour, followed by oil quenching. The two quenched steel grades groups were subjected to tempering process at different temperatures from $300^{\circ} \mathrm{C}$ to $650^{\circ} \mathrm{C}$ for $45 \mathrm{~min}$. The tempering process was followed by normal air cooling to room temperature.

Different phases were investigated by using SEM for tempered steels (at $575^{\circ} \mathrm{C}$ ).

Selected steel samples were prepared for microscopic examination after quenching and tempering process. Vickers hardness (HV) tests were carried out on polished steel samples. The hardness for investigated steels was measured after each tempering and quenching process. Each steel sample was measured 5 times; the average of the five measuring was taken. The measuring error was $\pm 2 \%$. Thermo-Calc software (version 3.1, database TCFE7) was used to investigate the formed phases at different temperature, the components and the amount of each phase.

\section{Result and Discussion}

The produced steels have chemical compositions as given in Table 1. Steel 1 
conforms the chemical composition of the conventional 56NiCrMoV7 steel, while the other two produced steels have nearly the same chemical composition except the micro addition of titanium in steel 2 and titanium + nitrogen in steel 3.

In the present study, two quenching mediums air and oil were used. Vickers hardness measurements of the quenched steels are given in Table 2.

The higher hardness after oil quenching comparing with air quenching could be attributed to the higher cooling rate. Optical microscope examination showed that the martensitic structure was obtained in the investigated steels after oil quenching whereas steel specimens subjected to air quenching exhibited some retained austenite in martensitic matrix (Figure 1).

Table 1. Chemical composition of investigated steels.

\begin{tabular}{|c|c|c|c|c|c|c|c|c|c|c|c|}
\hline \multirow{2}{*}{$\begin{array}{l}\text { Steel } \\
\text { No. }\end{array}$} & \multicolumn{11}{|c|}{ Chemical composition, wt\% } \\
\hline & $\mathrm{C}$ & $\mathrm{Si}$ & $\mathrm{Mn}$ & $\mathrm{P}$ & $S$ & $\mathrm{Cr}$ & Mo & $\mathrm{Ni}$ & $\mathrm{V}$ & $\mathrm{Ti}$ & $\mathrm{N}$ \\
\hline 1 & 0.585 & 0.029 & 0.393 & 0.011 & 0.012 & 1.51 & 0.605 & 1.48 & 0.086 & 0.0005 & 0.003 \\
\hline 2 & 0.587 & 0.046 & 0.416 & 0.012 & 0.013 & 1.54 & 0.617 & 1.56 & 0.091 & 0.0293 & 0.004 \\
\hline 3 & 0.654 & 0.044 & 0.461 & 0.015 & 0.012 & 1.58 & 0.628 & 1.55 & 0.093 & 0.0208 & 0.012 \\
\hline
\end{tabular}

Table 2. Hardness of investigated steels after quenching in air and oil.

\begin{tabular}{ccc}
\hline \multirow{2}{*}{ Steel } & & Hardness, HV \\
\cline { 2 - 3 } No. & After air quenching & After oil quenching \\
\hline 1 & 675 & 698 \\
2 & 710 & 748 \\
3 & 664 & 722 \\
\hline
\end{tabular}

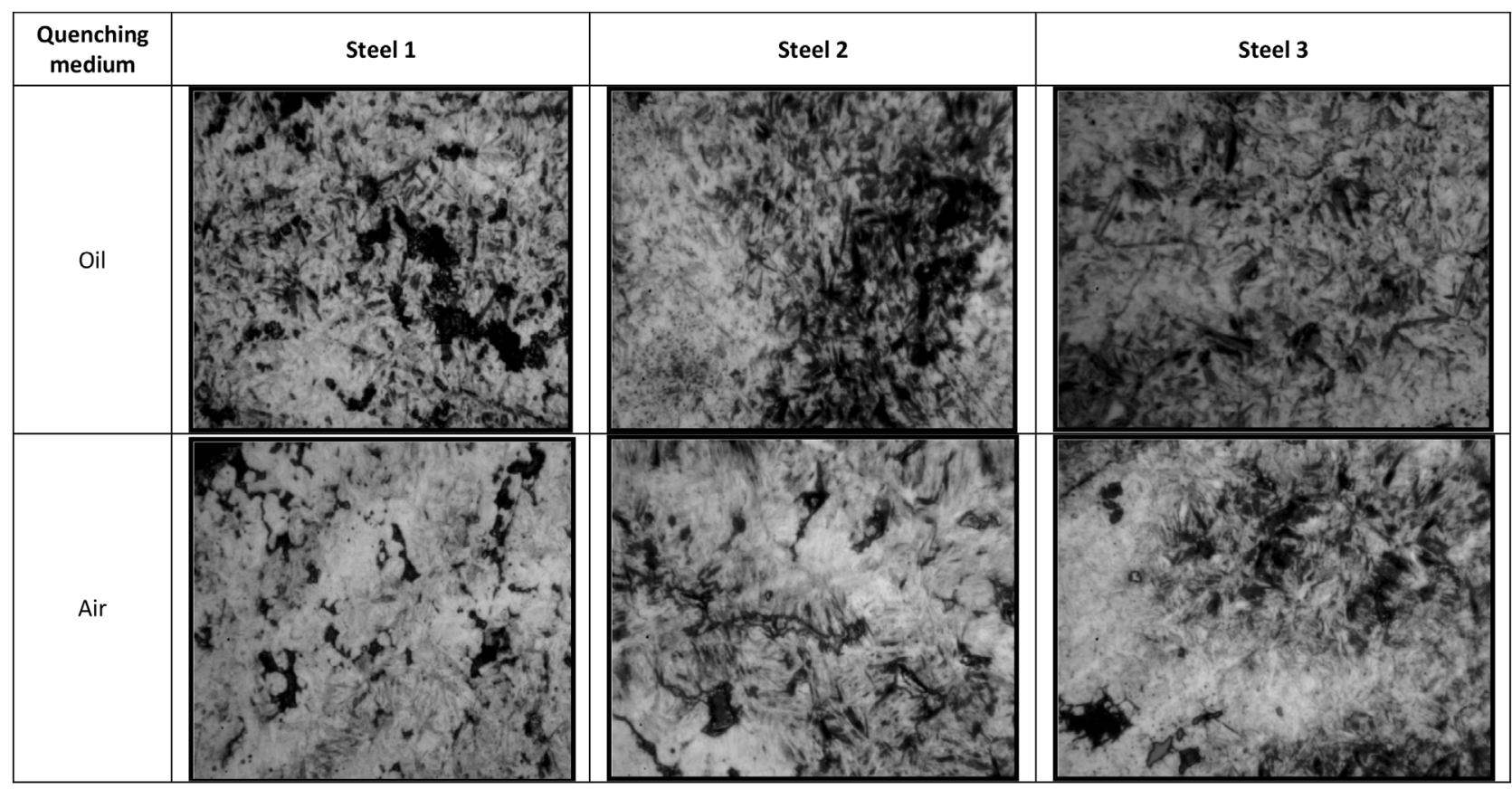

Figure 1. Microstructure of investigated steels after either oil quenching (from $850^{\circ} \mathrm{C}$ ) or air quenching (from $880^{\circ} \mathrm{C}$ ). 
The change in hardness of investigated steels by tempering for $45 \mathrm{~min}$ at each temperature between $300^{\circ} \mathrm{C}$ and $650^{\circ} \mathrm{C}$ after austenitizing and either air or oil quenching are illustrated in Figure 2 and Figure 3.

The results clarify progressive softening due to tempering of all investigated steels up to $500^{\circ} \mathrm{C}$. On the other hand, at higher temperature a distinct hardness peak is observed for each investigated steel at a definite tempering temperature, which should be attributed to the secondary hardening.

Tempering involves the segregation of carbon to lattice defects and precipitation of $\varepsilon$-iron carbide below $150^{\circ} \mathrm{C}$ and cementite above $200^{\circ} \mathrm{C}$, the decomposition of retained austenite, if any, into bainite at $150^{\circ} \mathrm{C}$ to $300^{\circ} \mathrm{C}$, the recovery

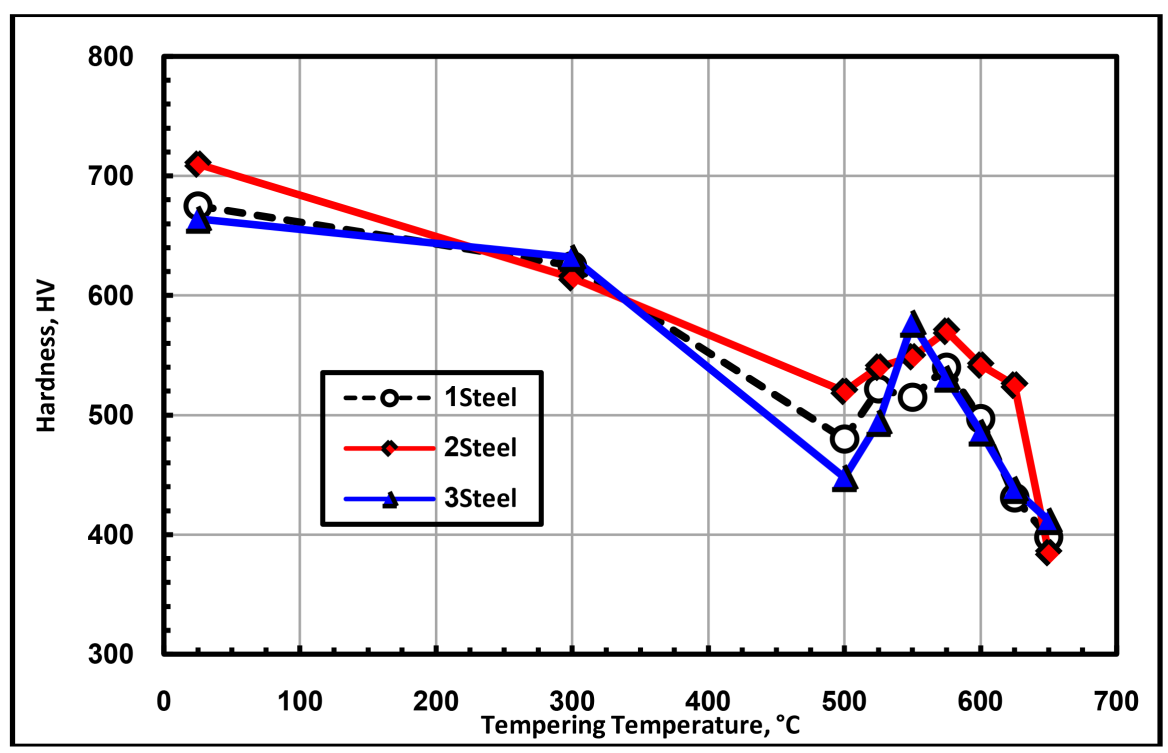

Figure 2. Change in hardness of investigated steels by tempering for $45 \mathrm{~min}$ at temperature range (from room temperature up to $650^{\circ} \mathrm{C}$ ) after austenitizing and air quenching.

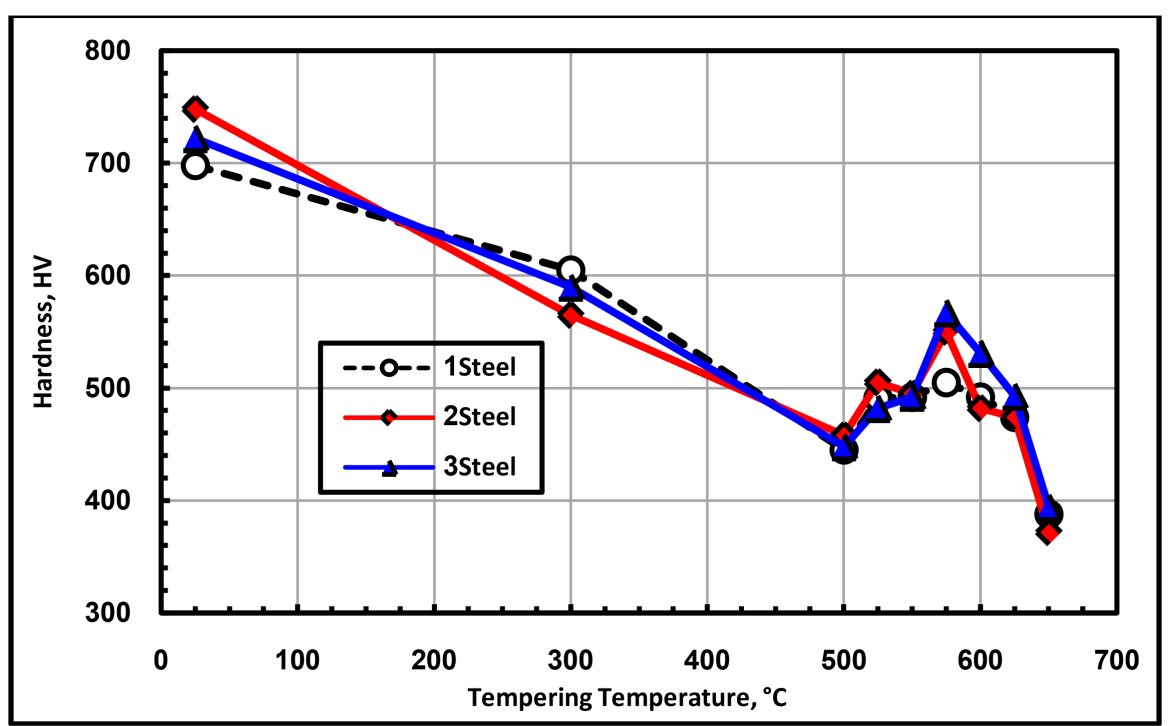

Figure 3. Change in hardness of investigated steels by tempering for $45 \mathrm{~min}$ at temperature range (from room temperature up to $650^{\circ} \mathrm{C}$ ) after austenitizing and oil quenching. 
$\left(>300^{\circ} \mathrm{C}\right)$ and recrystallization of the martensite structure above $600^{\circ} \mathrm{C}$ [18].

In plain-carbon steels, as in Fe-C alloys, there is a progressive softening accompanied by an increase in ductility as quenched martensite is tempered in the range from $100^{\circ} \mathrm{C}$ to $700^{\circ} \mathrm{C}$ [18]. If, however, carbide-forming alloying elements are added to the steel, a further and important strengthening reaction occurs in the temperature range from $500^{\circ} \mathrm{C}$ to $650^{\circ} \mathrm{C}$ which is called secondary hardening [18]. As a result of this reaction, a hardness approaching that of the as-quenched alloy can be achieved. This strengthening is a result of the replacement of coarse particles of $\mathrm{Fe}_{3} \mathrm{C}$, which dissolve, by a fine dispersion of alloy carbides such as chromium, molybdenum, vanadium and titanium carbides.

Tempering at up to $500^{\circ} \mathrm{C}$ resulted in a sharp decrease in hardness, which could be attributed to the initial cementite formation. However, it is noticed that the rate of softening of air-quenched steels (Figure 3 ) is considerably lower than that of oil-quenched steels (Figure 4) on tempering up to $500^{\circ} \mathrm{C}$. This may be attributed to the decomposition of retained austenite remained in air-quenched steels into bainite.

On the other hand, the hardness of investigated steels remarked increased as quenched martensite is tempered in the range of $500^{\circ} \mathrm{C}$ to $575^{\circ} \mathrm{C}$, and a distinct hardness peak is observed for every investigated steel at a definite tempering temperature of $550^{\circ} \mathrm{C}$ or $575^{\circ} \mathrm{C}$, should be attributed to the secondary hardening as a result of the replacement of coarse particles of cementite by a fine dispersion of alloy carbides [18].

It is noticed that the both modified $\mathrm{Ti}$ - and $\mathrm{Ti}-\mathrm{N}$-microalloyed $\mathrm{NiCrMoV}$ steels exhibit higher hardness peak than the conventional 56NiCrMoV7 steel. Whereas the hardness peak of modified Ti-steel (steel 2) is higher than that of

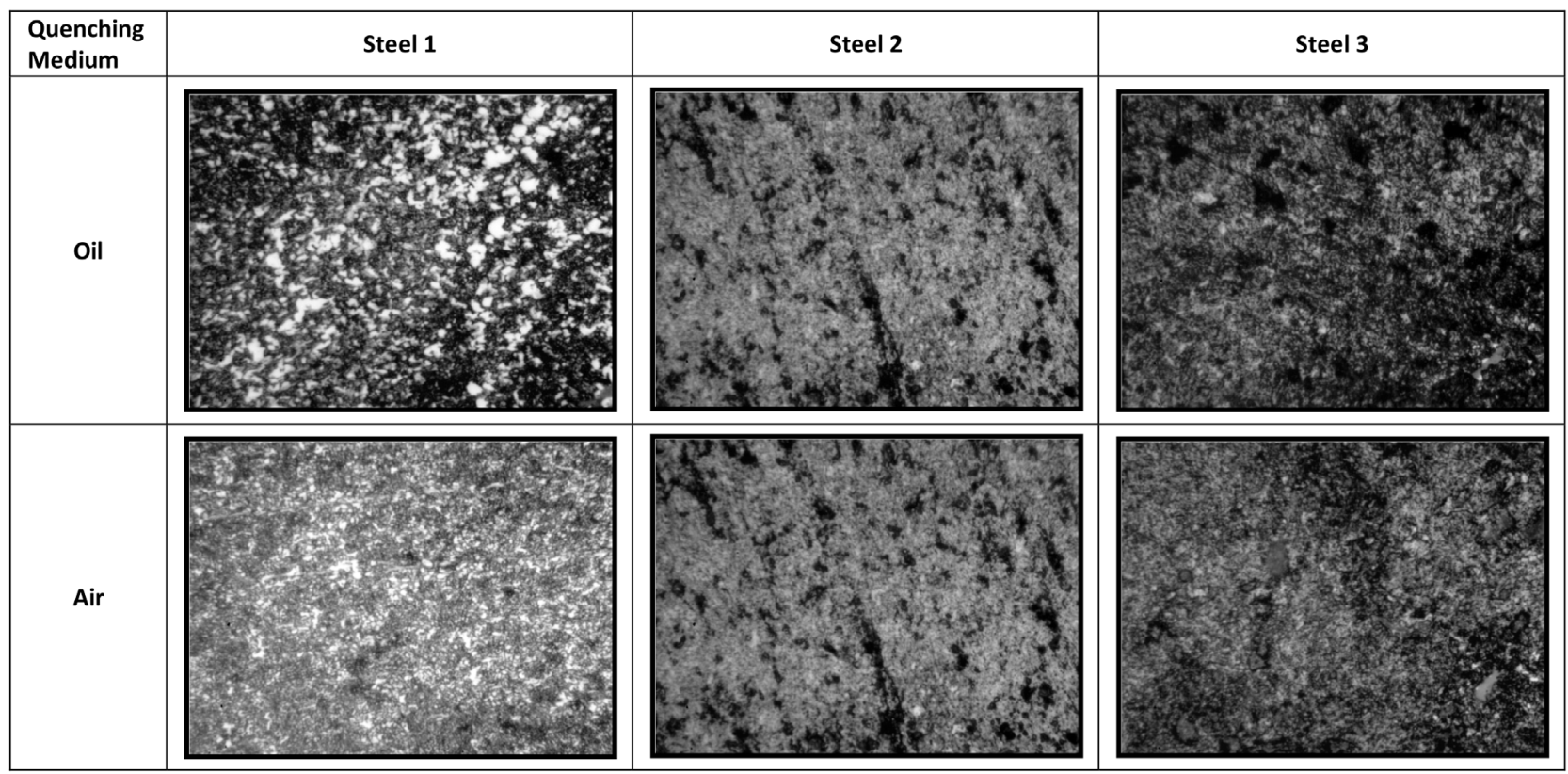

Figure 4. Microstructure of investigated tempered steels (at $650^{\circ} \mathrm{C}$ for $45 \mathrm{~min}$ ) after either oil quenching $\left(850^{\circ} \mathrm{C}\right.$ ) or air quenching $\left(880^{\circ} \mathrm{C}\right)$. 
conventional steel (steel 1) by $30 \mathrm{HV}$ and $45 \mathrm{HV}$ for the air quenched-tempered and oil quenched-tempered steels, respectively. The hardness peak of modified Ti-N-steel (steel 3) is also higher than that of conventional steel (steel 1) by 37 $\mathrm{HV}$ and $62 \mathrm{HV}$ for the air quenched-tempered and oil quenched-tempered steels, respectively.

It seems that the amount of $\mathrm{Ti}$ taken in solution is sufficient to increase the hardness peak in the two modified steels due to titanium carbide precipitation. However, the small difference in the hardness peak of both two modified steels (steels 2 and 3) may be explained by the lower solubility of titanium nitride comparing with the titanium carbide, with the result of untaken appreciable amount of nitrogen into solution for precipitation of titanium nitride.

Tempering at $600^{\circ} \mathrm{C}$ to $650^{\circ} \mathrm{C}$ resulted in a sharp decrease in hardness of all investigated steels. On over-aging, the precipitates on dislocation begin to coarsen and become more widely spaced and so become less effective in locking the dislocations leading to this softening (Figure 4).

At temperatures above $500^{\circ} \mathrm{C}$ the diffusion of alloying elements becomes significant, and they will start to develop carbides [19]. Alloy-carbide grows at the expense of cementite ( $\mathrm{Fe}_{3} \mathrm{C}$ alloy-carbide), either by in situ transformation (nucleation at cementite/ferrite interfaces followed by growth) or, following dissolution of cementite, by separate nucleation and growth in energetically favourable locations [20]. The effect of precipitation of alloy-carbides is evident, where precipitation of fine and ultra-fine alloy-carbides at about $550^{\circ} \mathrm{C}$ is responsible for the secondary hardening effect [21].

Thermo-Calc results showed that the stable phases and their ratios at both $500^{\circ} \mathrm{C}$ and $650^{\circ} \mathrm{C}$ for each steel grade as illustrated in Figure 5, which may demonstrate the behavior of hardness. For steel grade 1 as given in Figure 5, the increasing temperature from $500^{\circ} \mathrm{C}$ to $650^{\circ} \mathrm{C}$ is accompanied with disappearance of $\mathrm{M}_{7} \mathrm{C}_{3}$ (this leads to decrease hardness), growing of $\mathrm{M}_{23} \mathrm{C}_{6}$ from 0.031897 to 0.040758 molar ratio (this will cause an increase or decrease in hardness depending on size of formed carbide. Cementite is started to be formed at $650^{\circ} \mathrm{C}$ with molar ratio 0.064081 and graphite is dissolved with decreasing its molar ratios from 0.013874 to 0.00068 . The change of hardness is a result of all the previous mentioned changing of phases from the point of their morphology and quantities.

This is confirmed by the results of SEM, where the results showed that the carbides with type $\mathrm{M}_{23} \mathrm{C}_{6}$ for steel grade 1 were formed as illustrated by EDX as given in Figure 6. Where, $(\mathrm{Fe}, \mathrm{Mo}, \mathrm{Cr})_{3} \mathrm{C}_{6}$ mainly composed of iron carbides.

Thermo-Calc results showed that increasing tempering temperature from $500^{\circ} \mathrm{C}$ to $650^{\circ} \mathrm{C}$ for steel grade 2 (addition of titanium) - as illustrated in Figure 7-cause a disappearance, appear, growing, and converting phase(s) to another one.

- Dissolving of $\mathrm{M}_{3} \mathrm{C}_{2}$ phase where its molar ratio decreases from 0.02644 to 0.012016. Formation of $\mathrm{M}_{23} \mathrm{C}_{6}$ phase where its molar ratio grow up to 0.027985 . 

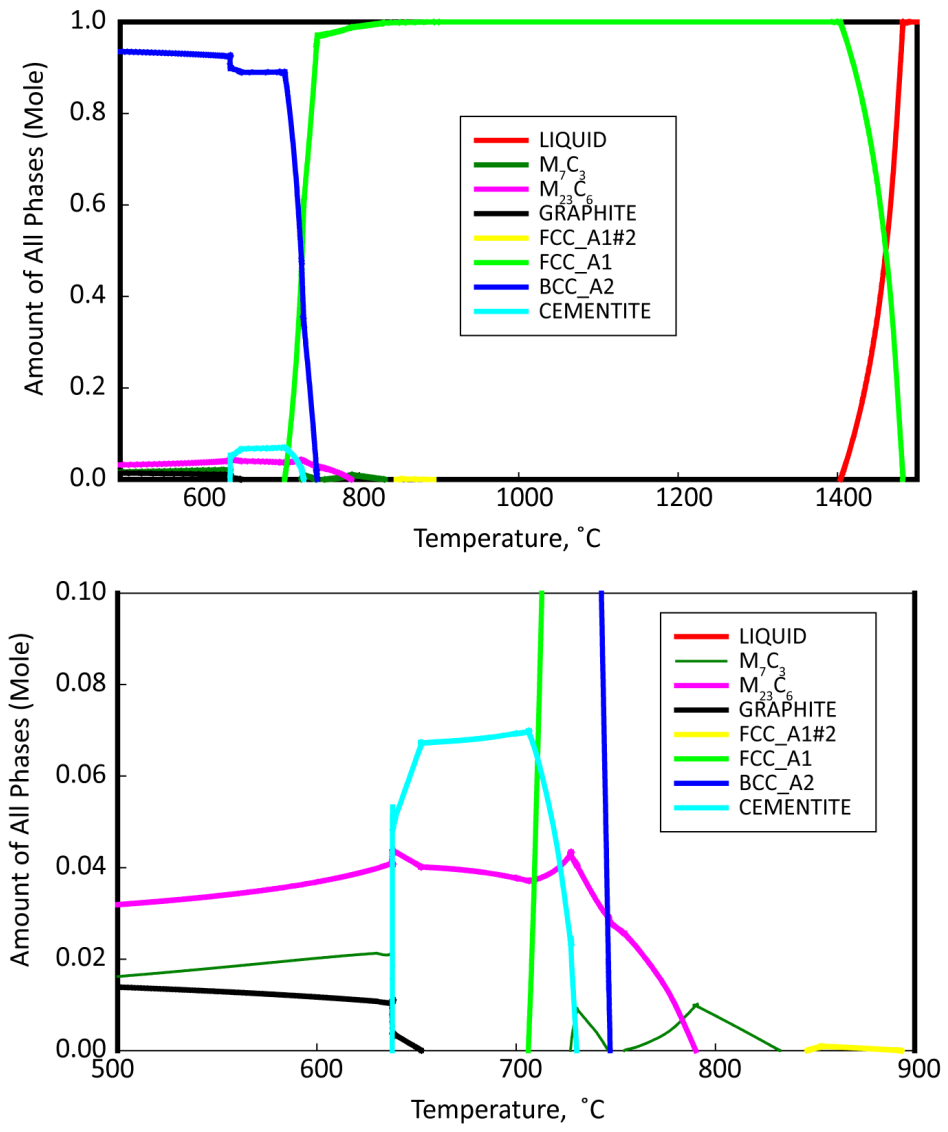

Figure 5. Effect of equilibrium temperature on phases of steel number 1.

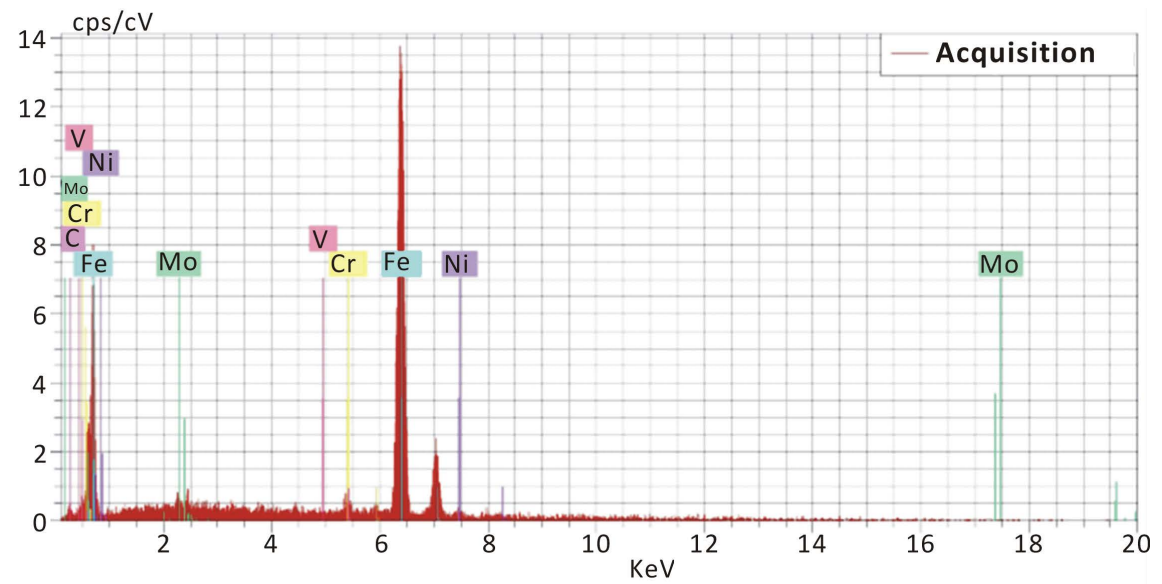

Figure 6. EDX of quenched steel sample 1 after tempering at $575^{\circ} \mathrm{C}$.

- Dissolving of graphite where its molar ratio decreases from 0.022053 to 0.013559 .

- Slightly decreases in BCC_A2 phase.

- Dissolving of MC_SHP phase and slightly dissolving of MC_ETA where its molar ratio decreases from 0.003444 to 0.003161 .

The net changes of morphology and quantities of different phases are contributing in decreasing of hardness. But it was noticed that the hardness increases 
at $550^{\circ} \mathrm{C}-575^{\circ} \mathrm{C}$ for steel number 2 . SEM results and EDX showed after tempering at $575^{\circ} \mathrm{C}$ (for oil quenched steel sample) that there are carbonitrides of types $[\mathrm{MC} \& \mathrm{M}(\mathrm{C}+\mathrm{N})](\mathrm{Fe}, \mathrm{Cr}, \mathrm{Mo}, \mathrm{Ti})(\mathrm{C}, \mathrm{N})$ as given in Figure 8 and Table 3. This may explain the appearance of hardness peak.

Thermo-Calc results showed that the influence of addition of nitrogen and titanium (steel grade 3) - as given in Figure 9-on phases behavior with increasing tempering temperature from $500^{\circ} \mathrm{C}$ to $650^{\circ} \mathrm{C}$ is illustrated as the following:
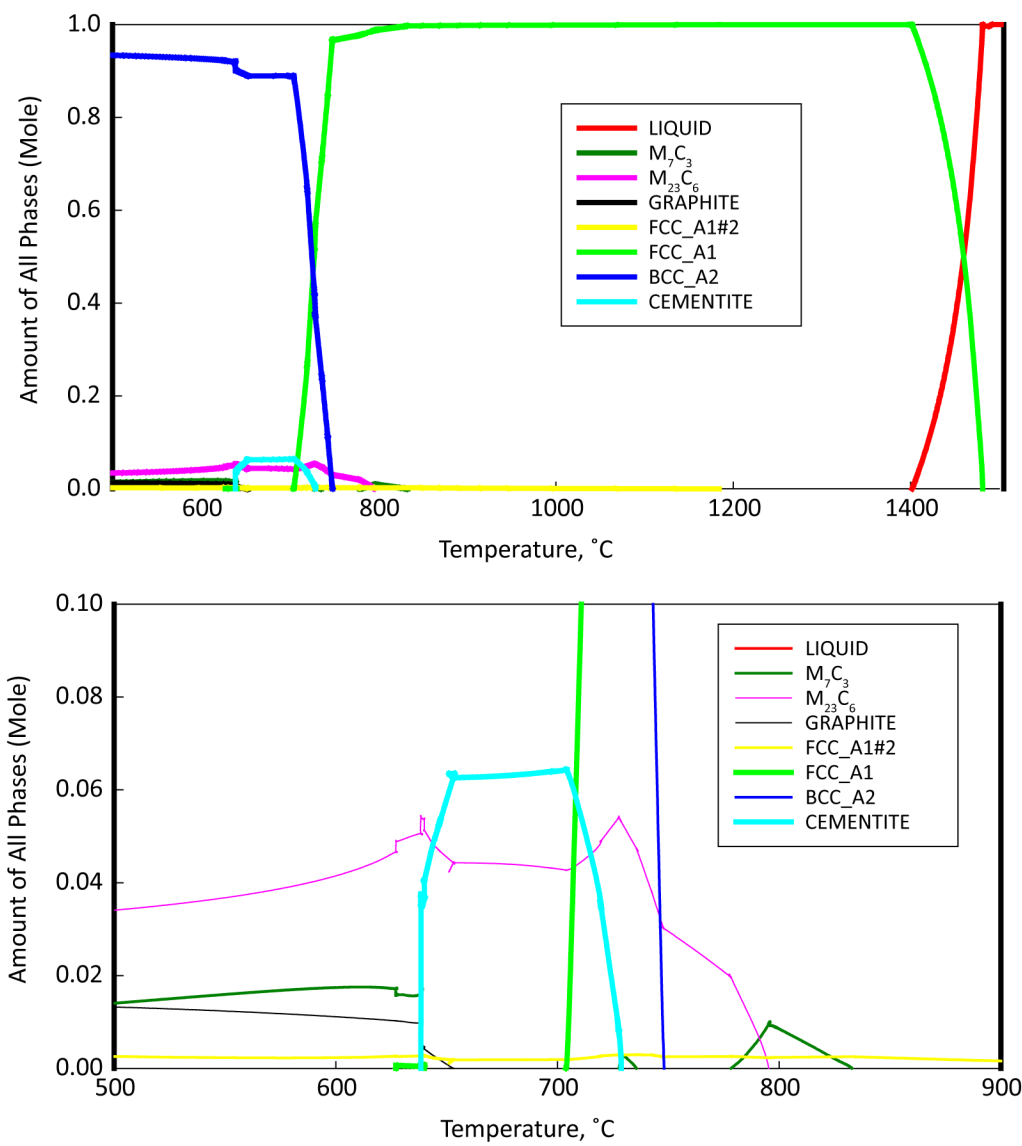

Figure 7. Effect of equilibrium temperature on phases of steel number 2.

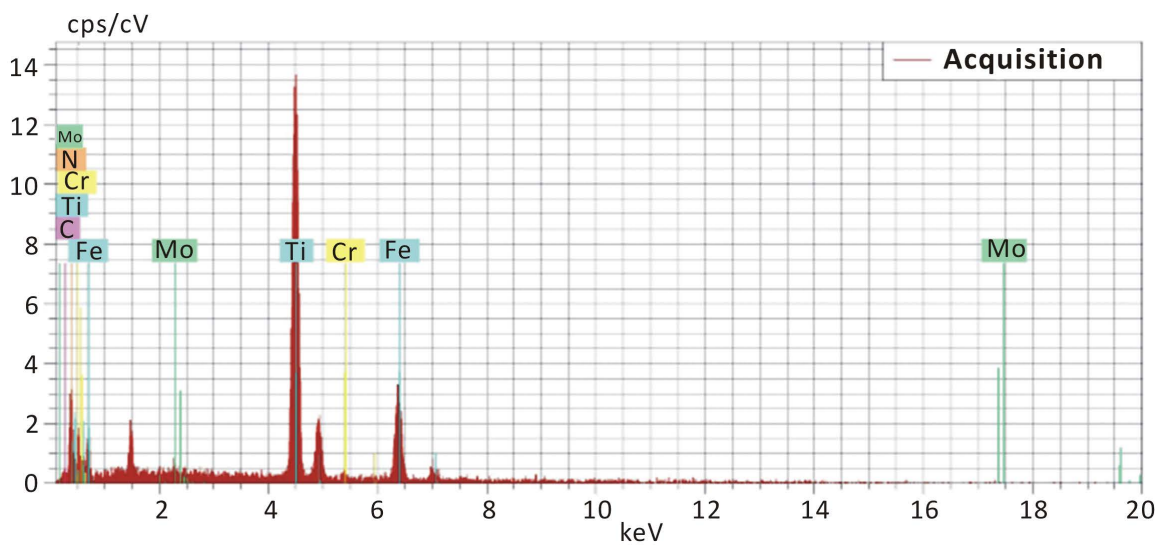

Figure 8. EDX of quenched steel sample 2 after tempering at $575^{\circ} \mathrm{C}$. 
Table 3. EDX of oil quenched steel number 2 after tempering at $575^{\circ} \mathrm{C}$.

\begin{tabular}{cc}
\hline Element(s) & Analysis or ratio \\
\hline $\mathrm{Fe}$ & 11.07 \\
$\mathrm{Mo}$ & 0.2 \\
$\mathrm{C}$ & 9.13 \\
$\mathrm{Cr}$ & 0.56 \\
$\mathrm{Ti}$ & 37.07 \\
$\mathrm{~N}$ & 41.98 \\
$\mathrm{Fe}+\mathrm{Cr}$ & 11.63 \\
$\mathrm{Fe}+\mathrm{Cr}+\mathrm{Mo}$ & 11.83 \\
$(\mathrm{Fe}+\mathrm{Cr}) / \mathrm{C}$ & 1.273823 \\
$(\mathrm{Fe}+\mathrm{Cr}+\mathrm{Mo}) / \mathrm{C}$ & 1.295728 \\
$(\mathrm{Fe}+\mathrm{Cr}+\mathrm{Mo}+\mathrm{Ti}) /(\mathrm{C}+\mathrm{N})$ & 0.95676
\end{tabular}
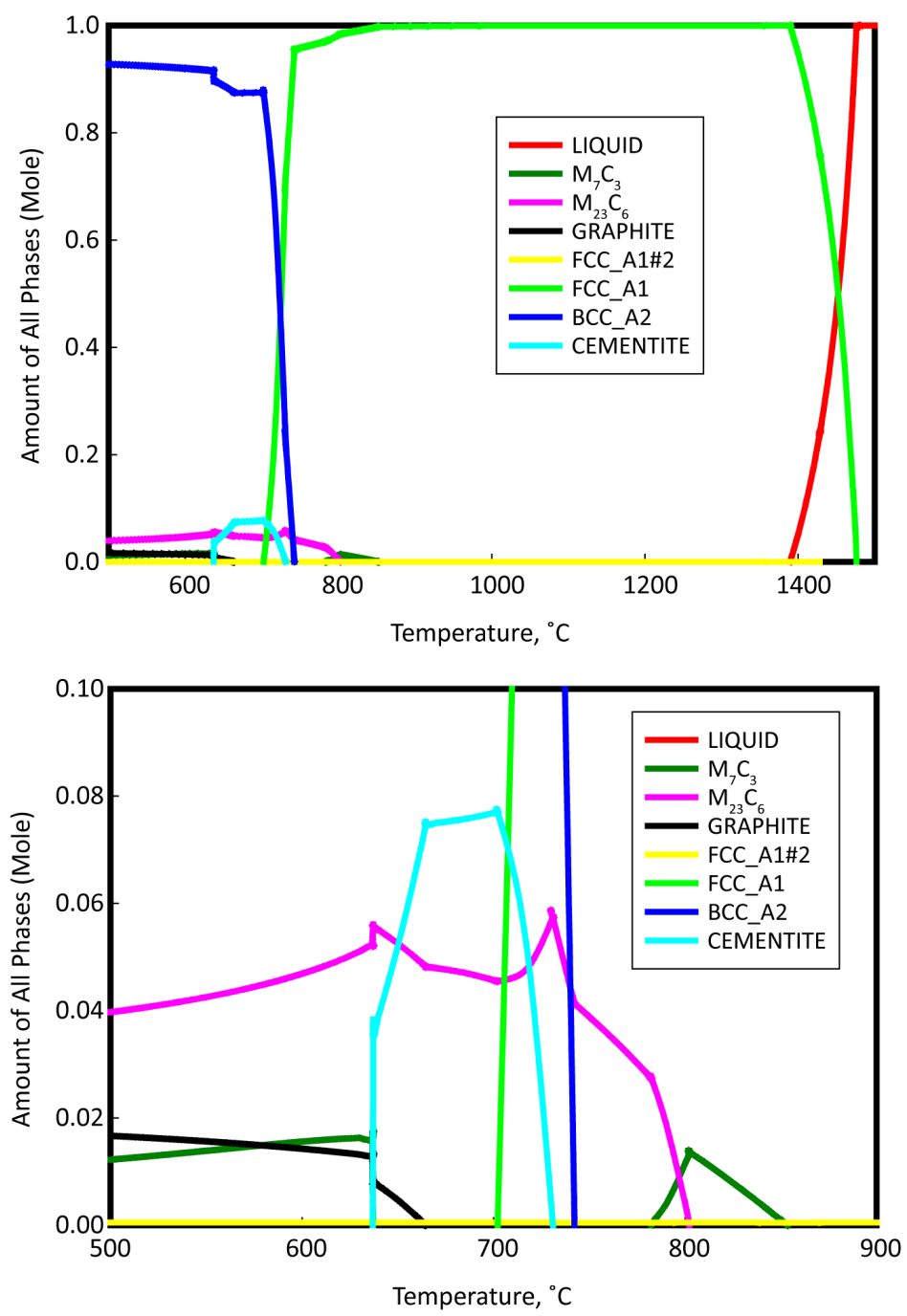

Figure 9. Effect of equilibrium temperature on phases of steel number 3. 
- Vanishing of $\mathrm{M}_{7} \mathrm{C}_{3}$ phase where its molar ratio was 0.01223 .

- Increasing molar ratio of $\mathrm{M}_{23} \mathrm{C}_{6}$ from 0.039721 to 0.052505 .

- Partial dissolving of graphite where its molar ration descending from 0.016677 to 0.004709 .

- Formation of cementite, where its molar ratio growing up to 0.052056 .

- FCC_A1\#2 phase is nearly unchanged (its molar ratio is about 0.000487 $0.000489)$.

- BCC_A2 molar ratio decreases from 0.928027 to 0.887837 .

For steel 3, SEM results and EDX showed that there are carbides or carbonitrides of Type $\mathrm{M}_{7} \mathrm{C}_{3}$, $(\mathrm{Fe}, \mathrm{Cr}, \mathrm{Mo}, \mathrm{Ti})(\mathrm{C}, \mathrm{N})$ as given in Figure 10 and Table 4.

Figure 5, Figure 7 and Figure 9 show the variation of phases with temperature according to Thermo-Calc (version 3.1 database TCFE7) of steel numbers 1, 2 and 3 respectively. It is noticed that the addition of $\mathrm{Ti}$ (steel grade 2) to the conventional die steel (steel grade 1) shrink the FCC phase region. This can be

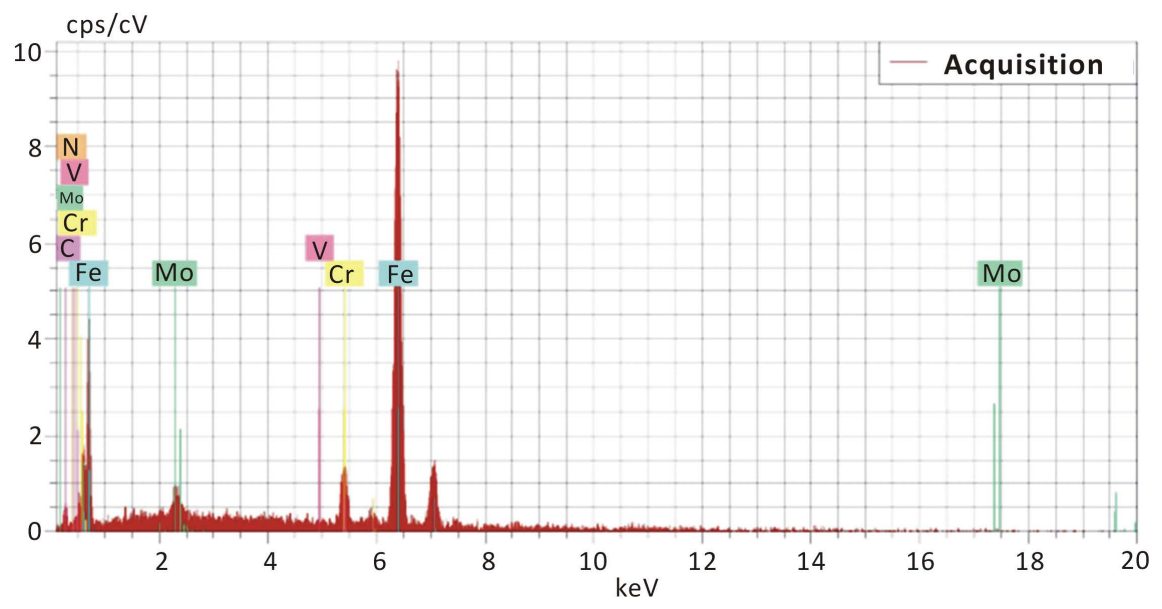

Figure 10. EDX of quenched steel sample 3 after tempering at $575^{\circ} \mathrm{C}$.

Table 4. EDX of quenched steel number 3, after tempering at $575^{\circ} \mathrm{C}$.

\begin{tabular}{cc}
\hline Element $(\mathrm{s})$ & Analysis or ratio \\
\hline $\mathrm{Fe}$ & 62.61 \\
$\mathrm{Mo}$ & 1.66 \\
$\mathrm{C}$ & 28.6 \\
$\mathrm{Cr}$ & 4.73 \\
$\mathrm{~V}$ & 0.04 \\
$\mathrm{~N}$ & 2.36 \\
$\mathrm{Fe}+\mathrm{Cr}$ & 64.27 \\
$\mathrm{Fe}+\mathrm{Cr}+\mathrm{Mo}$ & 69 \\
$(\mathrm{Fe}+\mathrm{Cr}) / \mathrm{C}$ & 2.247203 \\
$(\mathrm{Fe}+\mathrm{Cr}+\mathrm{Mo}) / \mathrm{C}$ & 2.412587 \\
$(\mathrm{Fe}+\mathrm{Cr}+\mathrm{Mo}+\mathrm{V}+\mathrm{Ti}) /(\mathrm{C}+\mathrm{N})$ & 2.229974 \\
\hline
\end{tabular}


attributed to that $\mathrm{Ti}$ is very strong ferritic stabilizer [22]. While, the addition of both $\mathrm{Ti}$ and $\mathrm{N}$ (steel number 3 ) to the conventional die steel (steel number 1), the FCC phase region resume expanded. This may be attributed to that addition of nitrogen compensate the effect of titanium because nitrogen is very strong austenitic stabilizer. The following phases are presenting in all steel grades FCC_A1, BBC_A2, graphite, $\mathrm{M}_{7} \mathrm{C}_{3}, \mathrm{M}_{23} \mathrm{C}_{6}$ and cementite. While the addition of nitrogen and/or titanium cause an appearing phase FCC_A1 = 3. The phase MC_ETA was disappeared with the addition of nitrogen. FCC_A1 phase was started to be formed for steel grades $1 \& 3$ at $710^{\circ} \mathrm{C}$ and for steel grade 2 at $717^{\circ} \mathrm{C}$.

Cementite was started to be formed at the expense of $\mathrm{M}_{7} \mathrm{C}_{3}$ phase at $637^{\circ} \mathrm{C}$ for the three steel grades. $\mathrm{M}_{7} \mathrm{C}_{3}$ phase mainly consists from $(\mathrm{Fe}, \mathrm{Cr})_{7} \mathrm{C}_{3}$ or $(\mathrm{Fe}, \mathrm{Cr}$, Mo) ${ }_{7} C_{3}$. Thermo-Calc results showed that $\mathrm{M}_{7} \mathrm{C}_{3}$ phase consists from mixture of different molar ratio from iron and chromium for steel grade one depending on temperature and carbon content, i.e., iron molar ratio in this phase ranging from 0.28 to 0.6 and chromium molar ratio ranging from 0.15 to 0.4 while carbon molar ratio is unchanged (0.3). The expected composition of $\mathrm{M}_{7} \mathrm{C}_{3}$ phase is $\left(\mathrm{Fe}_{0.28-0.58} \mathrm{Cr}_{0.12-0.42}\right) \mathrm{C}_{0.3}$.

The addition of titanium (steel grades 2 \& 3) has insignificant effect on the molar ratio of iron and carbon in $\mathrm{M}_{7} \mathrm{C}_{3}$ phase while the molar ratio of $\mathrm{Cr}$ decreases to a certain small extent which companied with appearance of molybdenum. The molar ratio of chromium and molybdenum are ranging from 0.11 to 0.42 and from 0.01 to 0.05 respectively. So, the expected $M_{7} C_{3}$ phase is $\left(\mathrm{Fe}_{0.28-0.58} \mathrm{Cr}_{0.11-0.42} \mathrm{Mo}_{0.01-0.05}\right) \mathrm{C}_{0.3}$. It can be concluded that the addition of titanium reduces the activity of chromium and increases the activity of molybdenum to be combined with carbon and form carbides. This data is in good agreement with experimental results.

$\mathrm{M}_{7} \mathrm{C}_{3}$ was started to be formed accompanied with growing of $\mathrm{M}_{23} \mathrm{C}_{6}$ at the expense of dissolving cementite at about $730^{\circ} \mathrm{C}$. It was noticed that $\mathrm{M}_{7} \mathrm{C}_{3}$ was dissolved rabidly at $740^{\circ} \mathrm{C}$, then it was started to grow again accompanied with dissolving of $\mathrm{M}_{23} \mathrm{C}_{6}$ at about $790^{\circ} \mathrm{C}$. Finally, $\mathrm{M}_{7} \mathrm{C}_{3}$ was resumed to be dissolved at about $820^{\circ} \mathrm{C}$.

$\mathrm{M}_{23} \mathrm{C}_{6}$ phase was started to be formed for steel grades $1 \& 3$ at before temperature $500^{\circ} \mathrm{C}$. It was started to be dissolved at temperature $730^{\circ} \mathrm{C}$ for steel grades $1 \& 3$ and at $638^{\circ} \mathrm{C}$ for steel $2 . \mathrm{M}_{23} \mathrm{C}_{6}$ phase completely was dissolved at $790^{\circ} \mathrm{C}$, $787^{\circ} \mathrm{C}$ and $802^{\circ} \mathrm{C}$ for steel grades $1,2 \& 3$ respectively. The dissolution of this phase accompanied with the growing of FCC_A1 phase.

$\mathrm{M}_{23} \mathrm{C}_{6}$ phase mainly consists of $\mathrm{Fe}, \mathrm{Cr}$ and Mo with different molar ratios, with constant molar ratio of $\mathrm{C}$. It was found that this phase has the formula $\left(\mathrm{Fe}_{0.45-0.72} \mathrm{Cr}_{0.05-0.25} \mathrm{Mo}_{0.0-0.09}\right) \mathrm{C}_{0.2}$ in steel grade 1 where, the iron content in this phase decreases by decreases the temperature while both chromium and molybdenum content increase. The expected formula of $\mathrm{M}_{23} \mathrm{C}_{6}$ is $\left(\mathrm{Fe}_{0.45-0.71} \mathrm{Cr}_{0.06-0.24} \mathrm{Mo}_{0.0-0.08}\right) \mathrm{C}_{0.2}$ for steel grades $2 \& 3$. The maximum ratios of $\mathrm{M}_{23} \mathrm{C}_{6}$ phase-relative to all phas- 
es-are $0.0318,0.0340$, and 0.0397 for steel grades 1,2 and 3 respectively.

Cementite was started to be formed at the expense of dissolving both graphite and $\mathrm{M}_{7} \mathrm{C}_{3}$ at $637^{\circ} \mathrm{C}$ for steel grades $1 \& 3$ and at $703^{\circ} \mathrm{C}$ for steel grade 2. Cementite was started to be dissolved accompanied with growing of FCC_Alat $710^{\circ} \mathrm{C}$ and completely was dissolved at $730^{\circ} \mathrm{C}$ for all steel grades. The dissolving of cementite accompanied with growing of MC phase for steel grade 1, FCC_A1\#2 for steel grade 2 , and $\mathrm{M}_{23} \mathrm{C}_{6}$ for steel grade 3 . It can be concluded that the presence of titanium delay the formation of cementite at higher temperature, while addition of nitrogen in presence of titanium compensate the effect of this dilatation, i.e., cementite was started to be formed at $637^{\circ} \mathrm{C}$. The analysis of the cementite phase of three steel grades are $\left(\mathrm{Fe}_{0.55-0.65} \mathrm{Cr}_{0.1-0.2}\right) \mathrm{C}_{0.25},\left(\mathrm{Fe}_{0.56-0.66} \mathrm{Cr}_{0.09-0.19}\right) \mathrm{C}_{0.25}$ and $\left(\mathrm{Fe}_{0.56-0.66} \mathrm{Cr}_{0.09-0.19}\right) \mathrm{C}_{0.25}$ respectively.

It was noticed that the disappearance of MC_ETA phase in steel grade 3, while it was be found in both steel grades $1 \& 2$. It was noticed that in steel grade 1 -as illustrated in Figure 5-at $637^{\circ} \mathrm{C}$, MC_ETA was started to be dissolved with $\mathrm{M}_{23} \mathrm{C}_{6}$ accompanied with disappearing both $\mathrm{M}_{7} \mathrm{C}_{6}$ and graphite while cementite was growing. At $730^{\circ} \mathrm{C}$, cementite was disappeared and MC_ETA began to grow with increasing temperature up to $746^{\circ} \mathrm{C}$, by further increasing in temperature MC_ETA was dissolving, to be vanished at $853^{\circ} \mathrm{C}$.

For steel grade 2 as illustrated in Figure 7, both FCC-A1\#2 and $\mathrm{M}_{23} \mathrm{C}_{6}$ phases were began to grow at the expanse of dissolving both MC_ETA and $\mathrm{M}_{3} \mathrm{C}_{2}$ at $585^{\circ} \mathrm{C}$. MC_ETA phase completely was disappeared at $725^{\circ} \mathrm{C}$. At $767^{\circ} \mathrm{C}$ MC_ETA was appeared again on the expanse of disappearing FCC_A1. Finally, MC_ETA disappeared at $900^{\circ} \mathrm{C}$ and appeared at $912^{\circ} \mathrm{C}$ and completely disappeared at $1000^{\circ} \mathrm{C}$.

MC_ETA mainly consists from 50\%, 30\% and 20\% molar ratios of C, V and Mo respectively for steel grade 1 -as illustrated in Figure 5-all over the temperature range $500^{\circ} \mathrm{C}-1000^{\circ} \mathrm{C}$. While, it consists from $50 \%, 25 \%-30 \%$ and $20 \%$ - 25\% molar ratios of carbon, $\mathrm{V}$ and Mo respectively for steel grade 2-as illustrated in Figure 7 -at temperature range $500^{\circ} \mathrm{C}$ up to $900^{\circ} \mathrm{C}$. These ratios were changed at temperature range $900^{\circ} \mathrm{C}-1200^{\circ} \mathrm{C}$, to be $0.47-0.50,0.13-0.25$ and $0.25-0.30$ respectively. The future investigation will be carried out using TEM to identify the formed phases.

\section{Conclusion}

$56 \mathrm{NiCrMoV7}$ tool steel can be modified through addition of titanium, with the result of increasing the hardness of tempered steel. Addition of nitrogen and titanium is not recommended for this type of steel. Results of Thermo-Calc program explained the change in hardness as a result of change in chemical compositions or due to change in tempering temperature. Thermo-Calc results found that the addition of titanium reduces the activity of chromium and increases the activity of molybdenum. Also, the presence of titanium delays the formation of cementite at higher temperature, while addition of nitrogen in presence of tita- 
nium compensates the effect of this dilatation, in addition to causing in disappearance of MC_ETA phase. The data of Thermo-Calc is in good agreement with the experimental results.

\section{Acknowledgements}

The authors thank Central Metallurgical Research \& Development institute (CMRDI), Egypt for supplying the raw materials, melting shop, and characterization tools. Also, the authors thank Institut fur Eisenhuttenkunde (IEHK), Germany for using Thermo-Calc. Programme, carrying out SEM.

\section{References}

[1] Sander, J., Hufenbach, J., Giebeler, L., Wendrock, H., Kühn, U. and Eckert, J. (2016) Microstructure and Properties of FeCrMoVC Tool Steel Produced by Selective Laser Melting. Materials and Design, 89, 335-341. https://doi.org/10.1016/j.matdes.2015.09.148

[2] Novotny, P.M. and Banerjee, M.K. (2016) Reference Module in Materials Science and Materials Engineering, Chapter: Tool and Die Steels. Elsevier, Amsterdam.

[3] Tang, L.H., Gao, C.X., Huang, J.L., Zhang, H.Y. and Chang, W.C. (2013) Dry Sliding Friction and Wear Behaviour of Hardened AISI D2 Tool Steel with Different Hardness Levels. Tribology International, 66, 165-173. https://doi.org/10.1016/j.triboint.2013.05.006

[4] Vogel, C., et al. (1993) Metallurgi for Ingeniører. 6th Edition, Akademisk Forlag, Aarhus.

[5] Hoyle, G. (1988) High Speed Steels. Butterworths, Petersburg.

[6] Bandyopadhyay, N., Briant, C.L. and Hall, E. L. (1985) Carbide Precipitation, Grain Boundary Segregation, and Temper Embrittlement in NiCrMoV Rotor Steels. $\mathrm{Me}$ tallurgical Transactions A, 16, 721-737. https://doi.org/10.1007/BF02814824

[7] Chen, F., Li, C.-D. and Cui, Z.-S. (2015) Modeling the Completely Recrystallized Grain Growth of NiCrMoV Rotor Steel. Journal of shanghai Jiaotong University (Science), 20, 600-605. https://doi.org/10.1007/s12204-015-1667-y

[8] Bandyopadhyay, N. and Briant, C.L. (1983) Caustic Stress Corrosion Cracking of NiCrMoV Rotor Steels The Effects of Impurity Segregation and Variation in Alloy Composition. Metallurgical Transactions A, 14, 2005-2019. https://doi.org/10.1007/BF02662368

[9] Wang, Q., Liu, X.S., Wang, W., Yang, C., Xiong, X. and Fang, H.Y. (2017) Mixed Mode Fatigue Crack Growth Behavior of Ni-Cr-Mo-V High Strength Steel Weldments. International Journal of Fatigue, 102, 79-91. https://doi.org/10.1016/j.ijfatigue.2017.05.001

[10] Liu, X., Cai, Z., Deng, X. and Lu, F. (2017) Investigation on the Weakest Zone in Toughness of $9 \mathrm{Cr} / \mathrm{NiCrMoV}$ Dissimilar Welded Joint and its Enhancement. Journal of Materials Research, 32, 3117-3127. https://doi.org/10.1557/jmr.2017.222

[11] Davanageri, B., Narendranath, S. and Kadoli, R. (2017) Effect of Sigma ( $\sigma$ ) Phase on Mechanical and Dry Sliding Wear Mahesh. Materials Today: Proceedings, 4, 10189-10196. https://doi.org/10.1016/j.matpr.2017.06.346

[12] Pippels, E., et al. (1999) Microstructure and Nanochemistry of Carbide Precipitates in High-Speed Steel S 6-5-2-5. Materials Characterization, 43, 41-55. https://doi.org/10.1016/S1044-5803(99)00003-0 
[13] Geller, Y. (1978) Tool Steels. Mir Publishers, Moscow.

[14] Højerslev, C. (2001) Tool Steels. Forskningscenter Risoe, Denmark. http://orbit.dtu.dk/files/7728903/ris_r_1244.pdf

[15] El-Faramawy, H.S., Ghali, S.N. and Eissa, M.M. (2012) Effect of Titanium Addition on Behavior of Medium Carbon Steel. Journal of Minerals and Materials Characterization and Engineering, 11, 1108-1112. https://doi.org/10.4236/jmmce.2012.1111118

[16] Eissa, M.M., Abd El-Aziz, A., Ghali, S., Halfa, H. and Saber, S. (2011) Effect of Microalloying Additions on the Microstructure and Mechanical Properties of Low Carbon Steel. Journal of Iron and Steel Research International, 18, 246-251.

[17] Eissa, M., El-Faramawy, H., Mattar, T., Fathi, A. and El-Fawakhry, K. (2002) Development of New Grade of Steel Shots for Casting Cleaning. Steel Research, 73, 69-76. https://doi.org/10.1002/srin.200200176

[18] El-Fawakhry, K.A., Mishreky, M.L. and Eissa, M.M. (1990) Secondary Hardening of Vanadium and Titanium Microalloyed Steels. Scandinavian Journal of Metallurgy, 19, 33-38.

[19] Zackery, V. (1962) Decomposition of Austenite by Diffusional Processes. John Wiley and Sons, Hoboken.

[20] Porter, D., et al. (1992) Phase Transformations in Metals and Alloys. 2nd Edition, Chapman \& Hall, Boca Raton.

[21] Wilson, R. (1975) Metallurgy and Heat Treatment of Tool Steels. McGraw-Hill Book Company, New York.

[22] Mallaiaha, G., Ravinder Reddy, P. and Kumar, A. (2014) Influence of Titanium Addition on Mechanical Properties, Residual Stresses and Corrosion Behaviour of AISI 430 Grade Ferritic Stainless Steel GTA Welds. Procedia Materials Science, 6, 1740-1751. https://doi.org/10.1016/j.mspro.2014.07.204 